\title{
Ранні ускладнення після операції ізольованого аортокоронарного шунтування: предиктори та періопераційна медикаментозна терапія
}

\author{
Шклянка І. В. ${ }^{1}$, Жарінов О. Й. ${ }^{2}$, Міхалєв К. О. ${ }^{3}$, Єпанчінцева О. А. ${ }^{1}$, Тодуров Б. М. ${ }^{1}$, \\ ${ }^{1}$ ДУ «Інститут серця МОЗ України», м. Київ, Україна \\ ${ }^{2}$ Національна медична академія післядипломної освіти ім. П. Л. Шупика, м. Київ, Україна \\ ${ }^{3}$ ДНУ «Науково-практичний центр профілактичної та клінічної медицини» Державного управління справами, \\ м. Київ, Україна
}

\begin{abstract}
Резюме. В одноцентровому дослідженні проаналізували дані, отримані під час клініко-інструментального обстеження 155 пацієнтів зі стабільною ішемічною хворобою серця (IXC), послідовно відібраних для операції ізольованого аортокоронарного шунтування (АКШ). У 66 пацієнтів протягом госпітального періоду були зареєстровані 84 ранні післяопераційні ускладнення, у 89 хворих ускладнень не відзначено. Групи пацієнтів з і без ускладнень порівнювали за демографічними показниками, супутніми хворобами, ехокардіографічними та лабораторними показниками, періопераційною терапією, особливостями операції АКШ.
\end{abstract}

Ключові слова: аортокоронарне шунтування, ранні післяопераційні ускладнення, статини, профілактика.

Операція аортокоронарного шунтування (АКШ) один з найефективніших методів відновлення порушеного коронарного кровотоку у хворих з ішемічною хворобою серця (IXC). Але кардіохірургічні втручання, особливо із застосуванням штучного кровообігу, пов'язані із розвитком таких ранніх післяопераційних ускладнень (РПУ), як післяопераційні порушення ритму серця, неврологічні розлади, ниркова і легенева недостатність, вторинні дисфункції тромбоцитів, що призводять до кровотечі, системна запальна реакція тощо [1-3]. У свою чергу, наслідком післяопераційних ускладнень є збільшення тривалості перебування пацієнтів у клініці та погіршення співвідношення «вартість-ефективність» надання медичної допомоги.

Мета цього дослідження полягала в оцінюванні предикторів виникнення РПУ в пацієнтів після ізольованого АКШ.

Матеріали і методи дослідження. В одноцентровому дослідженні проаналізовано дані, отримані під час клініко-інструментального обстеження 155 пацієнтів зі стабільною IXC, послідовно відібраних для операції ізольованого АКШ у ДУ «Інститут серця МОЗ України». Серед обстежених було 139 чоловіків $(89,7 \%)$ та 16 $(10,3 \%)$ жінок віком від 39 до 81 року, медіана віку - 62 (квартилі 55-67) роки. Стабільну стенокардію напруження зареєстрували у $151(97,4 \%)$ хворого, інфаркт міокарда (IM) раніше перенесли 125 (80,6 \%) хворих. Хронічна серцева недостатність $(\mathrm{XCH})$ виявлена в усіх 155 пацієнтів (100\%), серед них у 140 (90,3 \%) вираженість ознак ХСН відповідала ІІА стадії, у 6 (3,9 \%) ІІ Б стадії. Гіпертонічну хворобу (ГХ) діагностували у 142 пацієнтів, цукровий діабет 2-го типу відзначали у $39(25,2 \%)$ хворих, стентування коронарних артерій раніше здійснювали у $21(13,5 \%)$ пацієнта. Фракція викиду ЛШ (ФВ ЛШ) становила менше $40 \%$ у 39 пацієнтів (25,2 \%), 40-49\% - у 36 пацієнтів (23,2 \%). Усім 155 пацієнтам виконали ізольоване АКШ. У 10 (6,5\%) пацієнтів встановлено 1 шунт, у 35 (22,6\%) - 2 шунти, у $94(60,6 \%)-3$ шунти, у 14 (9\%) - 4 шунти та у $2(1,3 \%)-5$ шунтів. Пластику ЛШ проводили 26 $(16,8 \%)$ пацієнтам. У 134 (86,4 \%) пацієнтів реваскуляризацію міокарда було проведено з використанням штучного кровообігу. Перетискання аорти здійснювали у 126 (81,3\%) хворих, медіана тривалості перетискання аорти становила 18 (квартилі 14-23) хвилин.

У дослідження не включали пацієнтів з нестабільною стенокардією або гострим інфарктом міокарда, пацієнтів, що планувалися на комбіновані операції (АКШ у поєднанні з протезуванням клапанів серця), а також з будь-якими станами, що унеможливлювали виконання реваскуляризації міокарда.

Ранніми післяопераційними ускладненнями вважали виникнення післяопераційної фібриляції i/або тріпотіння передсердь (ПОФП/ТП) - 47 випадків, гострого пошкодження нирок - 14, гострої післяопераційної енцефалопатії - 7, гострих порушень мозкового кровообігу / транзиторних ішемічних атак (ГПМК/ TIA) - 4, гострої серцевої недостатності - 4, кровотечі, що потребувала подальшої реторакотомії - 4, IM - 1, гострої дихальної недостатності - 1 , значущої блокади з імплантацією штучного водія ритму (ШВР) - 1 та пневмонії - 1 випадок. Летальних випадків упродовж госпітального періоду у включених у дослідження пацієнтів не було. 
Результати та їх обговорення. Групи пацієнтів з та без РПУ значуще не відрізнялися за віком, статевою структурою та частотою виявлення супутніх хвороб. Індекс маси тіла (IMT) у пацієнтів з РПУ був більший, ніж у пацієнтів без ускладнень $\left(29,2(27,2-32,1) \mathrm{kг} / \mathrm{M}^{2}\right.$ проти $\left.28,0(24,9-30,5) \mathrm{kг} / \mathrm{M}^{2}, \mathrm{p}=0,019\right)$. Хоча значущої відмінності між групами щодо наявності ЦД не було, тяжку форму ЦД спостерігали частіше в пацієнтів з ускладненим перебігом післяопераційного періоду $(\mathrm{p}=0,025)$.

У групі з ускладненнями відзначався вищий показник інтерлейкіну-6 (ІЛ-6; 4,1 пг/мл проти 3,2 пг/мл, $\mathrm{p}=0,044)$. Порівнювані групи суттєво не відрізнялися за вихідними сироватковими рівнями гемоглобіну, тромбоцитів, глікемії натще, креатиніну та печінкових ферментів.

За даними ехокардіографії, значуще більший показник маси міокарда ЛШ, індексованої за зростом 2,7 відзначався у групі з ускладненнями (47,9 г/м 2,7 проти 43,6 г/м ${ }^{2,7}$ відповідно, $\left.p=0,008\right)$. Також спостерігали тенденцію до більшого розміру лівого передсердя (ЛП) у групі з ускладненим перебігом післяопераційного періоду.

Передопераційна медикаментозна терапія передбачала базисні препарати для лікування IXC, гіпотензивні препарати, засоби лікування та профілактики серцевої недостатності $(\mathrm{CH})$ та аритмій серця. Важливою значущою відмінністю між групами була більша кількість хворих, які приймали статини в групі без РПУ (91\% проти $70 \%$, p < 0,001). Причому високоінтенсивну терапію статинами приймали $15 \%$ пацієнтів цієї групи (таблиця 1).

У більшості пацієнтів при проведенні реваскуляризації міокарда імплантували 3 шунти, але у групі 3 ускладненнями спостерігалась тенденція до імплантації 4 та 5 шунтів. Тривалість перетискання аорти була більшою в пацієнтів з ускладненим перебігом післяопераційного періоду (20 хв проти 17 хв, $\mathrm{p}=0,049$ ). Також абсолютно всі пацієнти цієї групи потребували інотропної підтримки в післяопераційний період, причому тривалість інфузії інотропних засобів була більшою $(\mathrm{p}=0,039)$, що призвело до значно довшого перебування у відділенні інтенсивної терапії $(\mathrm{p}<0,001)$ (таблиця 1).

В уніваріантному регресійному аналізі з виникненням РПУ значуще або на рівні тенденції асоціювалися періопераційне приймання статинів (відношення шансів (ВШ) 0,384 (95 \% довірчий інтервал (ДІ) 0,202$0,731) ; \mathrm{p}=0,004)$, ступінь тяжкості ЦД (ВШ 1,412 (95\% ДІ 1,042-1,913); $\mathrm{p}=0,026)$, ступінь збільшення маси міокарда ЛШ/зріст (ВШ 1,389 (95 \% ДІ 1,043-1,851); $\mathrm{p}=0,025)$ та кількість імплантованих шунтів (загалом) (ВШ 1,487 (95\% ДІ 0,938-2,356); $\mathrm{p}=0,091$ ).

За даними мультиваріантного аналізу, незалежними предикторами виникнення РПУ після ізольованого АКШ, виявились періопераційне приймання статинів (ВШ 0,399 (95\% ДІ 0,208-0,764); $\mathrm{p}=0,006$ ) та ступінь тяжкості ЦД (ВШ 1,377 (95\% ДІ 1,006-1,884); $\mathrm{p}=$ 0,046).

Відтак, пацієнти, які в періопераційний період приймали статини у високих дозах упродовж $\geq 7$ діб або в низьких/середніх дозах мали ризик виникнення ранніх післяопераційних ускладнень після реваскуляризації міокарда у 2,5 раза нижчий за такий порівняно 3 пацієнтами, в яких передопераційна фармакотерапія взагалі не включала ці препарати. Крім того, ризик РПУ в пацієнтів із ЦД тяжкого ступеня в 1,4 раза більший за такий в осіб із ЦД середнього ступеня тяжкості та

\section{Таблиця 1}

Передопераційне приймання статинів та деякі інтраопераційні показники у порівнюваних групах

\begin{tabular}{|c|c|c|c|c|}
\hline \multicolumn{2}{|l|}{ Показники } & \multirow{2}{*}{$\begin{array}{l}\text { Без РПУ (n = 89) } \\
8(9)\end{array}$} & \multirow{2}{*}{$\begin{array}{l}3 \text { РПУ (n = 66) } \\
20(30,3)\end{array}$} & \multirow[t]{2}{*}{$\mathbf{p}$} \\
\hline \multirow{3}{*}{$\begin{array}{l}\text { Періопераційне при- } \\
\text { ймання статинів, n (\%) }\end{array}$} & Не приймали & & & \\
\hline & Низькі/помірні дози & $68(76,4)$ & $40(60,6)$ & \multirow[t]{2}{*}{0,003} \\
\hline & Високі дози $\geqslant 7$ днів & $13(14,6)$ & $6(9,1)$ & \\
\hline \multirow{4}{*}{ Кількість шунтів, n (\%) } & 1 & $7(7,9)$ & $3(4,5)$ & \multirow{4}{*}{0,041} \\
\hline & 2 & $20(22,5)$ & $15(22,8)$ & \\
\hline & 3 & $58(65,1)$ & $36(54,5)$ & \\
\hline & $(4-5)^{z}$ & $4(4,5)$ & $12(18,2)$ & \\
\hline \multicolumn{2}{|l|}{ Пластика ЛШ, n (\%) } & $19(21,3)$ & $7(10,6)$ & $0,086^{*}$ \\
\hline \multicolumn{2}{|c|}{ Тривалість штучного кровообігу, хв } & $84(68-99) n=76$ & $91(72-103) n=58$ & $\mathrm{H3}$ \\
\hline \multicolumn{2}{|c|}{ Тривалість перетискання аорти, хв } & $17(13-23) n=72$ & $20(15-25) n=54$ & 0,049 \\
\hline \multicolumn{2}{|c|}{ Тривалість перебування у реанімації, діб } & $2(2-2)$ & $2(2-3)$ & $<0,001$ \\
\hline
\end{tabular}

Примітка. * - статистична значущість точного критерію Фішера; z - статистично значуща відмінність у z-тесті (стовпчики), НЗ - не значимо. 
в 1,96 раза більший за такий у пацієнтів із Цд легкого ступеня.

Висновки. Переважну більшість ранніх ускладнень становили післяопераційні порушення ритму ПОФП/ТП, які є найпоширенішим ускладненням кардіохірургічних втручань. Особливостями пацієнтів 3 ускладненнями в ранній післяопераційний період були навність ЦД тяжкого ступеня, надлишкова маса тіла, вищий індекс маси міокарда, збільшення розмірів лівого передсердя, підвищений доопераційний рівень ІЛ-6, більша тривалість перетискання аорти й інотропної підтримки. Наявність ЦД тяжкого ступеня та відсутність терапії статинами в періопераційний період виявилися незалежними предикторами виникнення РПУ. Під час підготовки пацієнтів з IXC до проведення планової реваскуляризації міокарда необхідно враховувати зазначені фактори виникнення ускладнень.

\section{Список використаних джерел}

\section{References}

1. Montrief T, Koyfman A, Long B. Coronary artery bypass graft surgery complications: A review for emergency clinicians. Am J Emerg Med. 2018 Dec;36(12):2289-97. https://doi.org/10.1016/j.ajem.2018.09.014

2. Rubanenko OA, Fatenkov OV, Khokhlunov SM, Limareva LV. [Atrial Fibrillation After Coronary Artery Bypass Grafting]. Kardiologiia. 2017 Apr;57(4):53-57. (in Russian).

3. Mehta A, Gleason T, Wechsler L, Winger D, Wang L, Thirumala PD. Perioperative stroke as a predictor of mortality and morbidity in patients undergoing CABG. J Clin Neurosci. 2017 Oct;44:175-9. https://doi. org/10.1016/j.jocn.2017.06.035

Конфлікту інтересів немає.

\title{
Early Complications after Isolated Coronary Artery Bypass Grafting: Predictors and Perioperative Pharmacological Therapy
}

\author{
Shklianka I. V., ${ }^{1}$, Zharinov O. J. ${ }^{1}$, Mikhaliev K. O. ${ }^{3}$, Yepanchintseva O. A. ${ }^{2}$, Todurov B. M. ${ }^{2}$ \\ ${ }^{1}$ Shupyk National Medical Academy of Postgraduate Education, Kyiv, Ukraine \\ ${ }^{2}$ Heart Institute of Healthcare Ministry of Ukraine, Kyiv, Ukraine \\ ${ }^{3}$ State Scientific Institution «Scientific and Practical Center of Preventive and Clinical Medicine» State Government Affairs, \\ Kyiv, Ukraine
}

Abstract. Cardiac surgery is associated with the development of early postoperative complications (EPC) such as postoperative arrhythmias, neurological disorders, renal and pulmonary insufficiency, secondary platelet dysfunction, systemic inflammation response, etc.

The aim. To determine predictors of early postoperative complications in patients after isolated CABG.

Materials and methods. In a single-center study, data from clinical and instrumental examination of 155 patients with stable coronary heart disease (CHD), successively selected for an isolated coronary artery bypass surgery (CABG), were analyzed. In 66 patients, 84 early postoperative complications were reported during the hospital period, 89 patients had no complications. Groups of patients with and without complications were compared in terms of demographic indicators, comorbidities, echocardiographic and laboratory parameters, perioperative therapy, and features of CABG surgery.

Results. Most of the early complications $(56 \%)$ were the cases of postoperative atrial fibrillation. A unifactor analysis showed that the patients with complications in the early postoperative period typically had severe diabetes $(p=0.025)$, I and II degree of obesity $(p=0.070)$, LV hypertrophy $(p=0.008)$, enlarged left atrium $(p=0.068)$; elevated preoperative level of IL-6 ( $\mathrm{p}=0.044)$; absence of statin therapy in perioperative period $(\mathrm{p}<0.001)$ and prolonged duration of aortic clamping $(\mathrm{p}=0.049)$. According to the multivariate analysis, the risk of EPC after CABG was 2.5 times higher in patients who did not take statins in the perioperative period, compared to those who received high doses of statins for $\geq 7$ days or low/ moderate doses of statins. In patients with severe diabetes, the risk of EPC was 1.96 times higher than that in patients with mild diabetes.

Conclusions. High-dose statin therapy for $\geq 7$ days prior to surgery allowed to reduce the risk of early complications, particularly, postoperative atrial fibrillation.

Keywords: coronary artery bypass grafting, early postoperative complications; statins; prevention.

Стаття надійшла в редакцію 26.03.2019 р. 